\title{
FINANSOWANIE OPEN ACCESS
}

\author{
Anna Wałek \\ Biblioteka Główna i OINT \\ Politechniki Wrocławskiej
}

Open Access, czasopisma elektroniczne, modele finansowe Open Access, The Public Library of Science (PLoS)

Kwestia finansowania otwartego dostępu do zasobów wiedzy jest sprawą niezwykle istotną, a jednak najczęściej pomijaną w polskich opracowaniach na ten temat. W Polsce Open Access pojmowany jest nadal bardziej jako pewna idea, lącząca zmagania entuzjastów, często oparta na zasadzie wolontariatu. Niektórzy uważają, że debata na temat Open Access w istocie nie dotyczy spraw ekonomicznych, ale nieograniczonego dostępu do publikowanych wyników badań naukowych, również za pomocą modelu OA ${ }^{1}$, który z założenia ma być bezpłatny. Niestety, nie jest on pozbawiony kosztów. Mimo iż autor nie pobiera honorarium za swoją pracę, są koszty administracyjne, systemowe, koszty recenzji i inne, które muszą być pokryte.

Obecnie funkcjonuje kilka modeli finansowania OA:

- publikację finansuje autor - aby opublikować swój artykuł w czasopiśmie OA, musi uiścić opłatę autorską (publication fee);

- publikowanie prac swoich pracowników finansuje instytut naukowy lub uczelnia - często w ramach prowadzonego repozytorium (archiwum e-printów), czasopisma OA lub na stronie domowej;

- dofinansowanie pochodzi z zewnętrznych instytucji, dotacji rządowych, grantów;

- model podwójny - dochody pochodzące ze sprzedaży wersji drukowanej przeznaczone są na sfinansowanie wolnego dostępu w wersji online;

- model współdzielony - instytucje członkowskie, takie jak biblioteki czy towarzystwa naukowe wspólnie utrzymują czasopismo OA i całe jego zaplecze techniczne;

- płatne członkostwo w wydawnictwie OA - wydawnictwo OA oferuje instytucjom naukowym udział wiążący się ze składką członkowską w zależności od wybranej formy członkostwa, instytucja ma prawo do opublikowania określonej liczby artykułów w ciągu roku;

- model hybrydowy - wydawnictwo oferuje autorom możliwość wpłacenia pewnej kwoty w celu "uwolnienia” artykułu publikowanego w czasopiśmie nie mającym statusu OA. Po dokonaniu opłaty artykuł dostępny jest bez ograniczeń.

A. Gass: Paying to Free Science: Costs of Publication as Costs of Research. „Serials Review" 2005, vol. 31, no. 2, p. 103. 
Pytanie o to, jak finansować koszty recenzowanych artykułów naukowych w wolnym dostępie jest niezwykle ważne. Odpowiedzią wydawców OA, takich jak The Public Library of Science (PLoS) jest, aby przy wyeliminowaniu opłat za dostęp wydawcy byli opłacani za usługi, których dostarczają autorom, instytucjom i środowisku naukowemu (przynajmniej w zakresie biologii i medycyny), jako dostawcy tak usług jak i systemu. W tym wypadku wydawcy pobieraja opłaty za udostępnianie i prowadzenie serwisu. Obejmują one recenzje, przygotowanie zaakceptowanego tekstu do publikacji, umieszczenie go w sieci itd. W zamian za jednorazową zapłate wydawcy OA, tacy jak PLoS czy BioMed Central, nie nakładają na publikację żadnych ograniczeń i jest ona w pełni dostępna w ramach czasopisma czy repozytorium².

Jednym z najliczniej reprezentowanych stanowisk w sprawie finansowania publikowania w wolnym dostępie jest opinia, że powinni to robić sami autorzy ze środków otrzymywanych w ramach grantu od instytucji sponsorującej badania naukowe lub od pracodawcy.

Jedną z propozycji pokrycia opłat autorskich był też pomysł, aby były one realizowane $z$ budżetów bibliotek instytucji, z którymi związani są autorzy ${ }^{3}$. Pomysłodawcy tłumaczyli koncepcję tym, że to właściwie biblioteki mają szansę zaoszczędzić najwięcej na wprowadzeniu OA. Rozwiązanie to miałoby bowiem wpływ na zmniejszenie nakładów ponoszonych przez biblioteki na prenumeratę czasopism. Biblioteki Uniwersytetu Cornell w Stanach Zjednoczonych (Cornell University Libraries) w 2004 r. przeprowadziły analizę nakładów, jakie ponoszą uczelnie na prenumeratę czasopism naukowych w porównaniu z tym, ile publikuja ich pracownicy. Wynikiem był Report of the Cornell University Library's Task Force on Open Access Publishing ${ }^{4}$. Jego autorzy jednak są sceptycznie nastawieni do modelu OA, starają się bowiem udowodnić, że model OA nie przyniesie uczelni rzeczywistych oszczędności. Wręcz przeciwnie, biorąc pod uwagę liczbę artykułów publikowanych rocznie przez pracowników Cornell University i średnie koszty związane $z$ ich udostępnieniem $w$ recenzowanym czasopiśmie OA, obliczyli, że nakłady na czasopisma wzrosną, jeśli biblioteka przeznaczy swoje dotychczasowe fundusze na pokrycie składek autorskich, nawet w przypadku gdyby większość wydawców przeszła na model OA ${ }^{5}$. Autorzy raportu podkreślaja, że model OA nie może być traktowany jako uniwersalne rozwiązanie kwestii czasopism naukowych, ale bez wątpienia może być pragmatycznym rozwiązaniem w konkretnych przypadkach 6 .

Jedna z konkluzji raportu Cornell University, która zakłada, że koszty wielu instytucji naukowych i ich bibliotek wzrosną, jeśli OA stanie się powszechny, jest zdaniem wielu komentatorów nietrafna, z założenia bowiem koszty publikowania w modelu OA powinny być traktowane jako integralna część kosztów badań naukowych, a dotyczą one zarówno instytucji, w której badania te sa prowadzone, jak i zewnętrznych agencji sponsorujących naukę poprzez przy-

${ }^{2}$ Ibidem.

3 ibidem.

${ }^{4}$ Report of the Cornell University Library's Task Force on Open Access Publishing. [online]. [dostęp: 14.05.2010]. Dostępny w World Wide Web: <http://ecommons.cornell.edu/ bitstream/1813/193/3/OATF_Report_8-9.pdf>.

${ }^{5}$ Ibidem.

${ }^{6}$ Ibidem 
znawanie grantów. Zatem koszty publikacji powinny być ponoszone nie tylko przez instytucje naukowe (czy, jak niektórzy twierdzą, biblioteki), ale również, a może przede wszystkim, przez grantodawcę finansującego badania, których wynikiem jest publikacja? ${ }^{7}$.

W Stanach Zjednoczonych wiele instytucji finansujących badania naukowe pośrednio lub bezpośrednio finansuje również publikację artykułów naukowych. Największa na świecie rządowa instytucja finansująca badania z zakresu tzw. life sciences - NIH (The US National Institutes of Heath) pozwala autorom na wykorzystywanie funduszy z grantów do finansowania publikacji, także OA. W 2005 r. na ten cel przeznaczano ok. $1 \%$ wartości grantów, co dawało ok. 2500 dolarów na artykuł ${ }^{8}$. NIH deklarowało już w 2005 r. wydawanie ok. 30 milionów dolarów na bezpośrednie koszty publikacji. Wynikiem sponsorowanych przez $\mathrm{NIH}$ badań jest średnio 60-65 tys. publikacji rocznie. Zatem na każdy artykuł przeznaczono ok. 450-500 dolarów. W porównaniu z prawie 14 mld dolarów, które w 2003 r. NIH przeznaczyła na granty badawcze, kwota na finansowanie publikacji to jedynie $0,22 \%$ ogólnego budżetu ${ }^{9}$.

Jednym z problemów autorskiego modelu finansowania OA jest rozbieżność, jaka może zaistnieć pomiędzy naukami ścisłymi, medycznymi czy biologicznymi a naukami humanistycznymi i społecznymi, gdzie system finansowania i uzyskiwania grantów różni się zasadniczo, zwłaszcza jeśli chodzi o same kwoty dotacji ${ }^{10}$.

Innym modelem finansowania jest praktykowany przez niektórych wydawców model oparty w całości lub częściowo na opłatach członkowskich. Dotyczy to głównie stowarzyszeń i towarzystw naukowych będących jednocześnie wydawcami czasopism naukowych. W przypadku PLoS Institutional Membership członkowie zwykle pokrywają do $50 \%$ autorskiej opłaty, resztę ponosi instytucja, która finansuje prowadzone przez autora badania. W przypadku autorów z instytucji, które nie mają członkowskiej umowy z wydawcą OA (większość autorów piszących dla czasopism PLoS), opłaty autorskie pochodzą zwykle $z$ grantów lub innych zewnętrznych źródeł finansowania, rzadziej natomiast z funduszy instytucji macierzystych ${ }^{11}$.

Niektóre opłaty ponoszone przez instytucje macierzyste są rekompensowane przez odpowiednie agencje finansujące badania. Dwie największe światowe fundacje finansujące badania z nauk biomedycznych: Welcome Trust i Howard Hughes Medical Institute w całości pokrywają koszty publikacji sponsorowanych przez siebie badaczy w czasopismach Open Access ${ }^{12}$.

Model finansowy i koszty ponoszone przez wydawców OA można przeanalizować na przykładzie PLoS. W 2003 r., kiedy na rynku ukazał się tytuł „PLoS Biology”, przewidywano, że koszt opublikowania jednego artykułu w czasopiśmie wyniesie ok. 1500 dolarów ${ }^{13}$. Ponieważ PLoS zapowiedział, że na łamach swoich czasopism będzie publikował tylko najbardziej wartościowe i najlepsze artykuły, oznacza to, że około $90 \%$ nadesłanych do redakcji

\footnotetext{
${ }^{7}$ A. Gass: Paying to Free Science..., op. cit., s. 104.

${ }^{8}$ Ibidem, s. 105.

${ }^{9}$ Tamże, s. 104.

${ }^{10}$ ibidem.

11 Ibidem.

12 ibidem.

${ }^{13}$ D. Butler: Who will pay for open access? „Nature” 2003, vol. 425, pp. 554-555.
} 
i zrecenzowanych prac zostanie odrzucona. Sam proces recenzowania tysięcy artykułów jest jednak niezwykle kosztowny, dlatego też specjaliści zakładali, że koszty publikacji będą wyższe, niż zapowiadane 1500 dolarów ${ }^{14}$. Dla wielu wydawców polityka finansowa PLoS była niezrozumiała. Publikowanie w wersji elektronicznej powinno zredukować koszty produkcji o około $20 \%$ w porównaniu z wielonakładowym czasopismem. Pozostaje jednak wciąż wiele kosztów o charakterze personalnym i administracyjnym ${ }^{15}$.

W 2006 roku PLoS musiał zmierzyć się z kryzysem finansowym. Z obliczeń specjalistów wynikało bowiem, że organizacja zaczęła ponosić straty sięgające w 2005 r. min dolarów. Dochody PLoS pochodzące z reklam i opłat autorskich pokrywały zaledwie $35 \%$ kosztów. Chociaż dochody z roku na rok rosły (od 0,75 mln dolarów w latach 2003-2004 do 0,9 mln w 2005 r.), to mimo wszystko nie pokrywały wydatków szacowanych na 1,5 do $5,5 \mathrm{mln}$ w ciagu trzech lat ${ }^{16}$.

Polityka firmy w początkowych latach działalności bazowała w dużej mierze na dotacjach. 9 mln dolarów PLoS otrzymał od Fundacji Gordona i Betty Moore'ów, $4 \mathrm{mln}$ dolarów od Sandler Family Supporting Foundation. Pieniądze z tych źródeł pokryły $65 \%$ kosztów funkcjonowania PLoS, szybko jednak się wyczerpywały ${ }^{17}$.
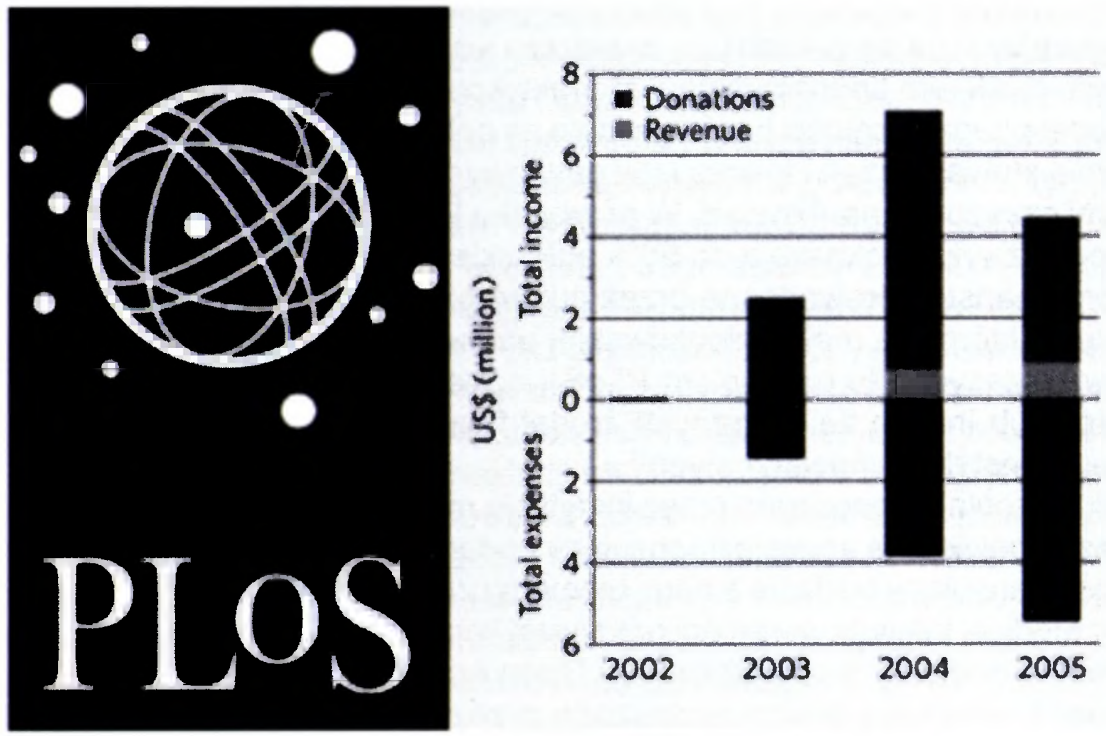

Rys. 1. Przychody i wydatki PLoS w latach 2002-2005 (na wykresie w kolorze jasnoszarym zaznaczono dochody z tytułu reklam i opłat autorskich, natomiast kolorem ciemnoszarym otrzymane dotacje zewnętrzne).

Żródło: D. Butler: Open Access journal hits rocky times. „Nature” 2006 vol. 441 [online]. [dostęp: 3.09.2010]. Dostępny w World Wide Web: <http://www.nature.com/nature/journal/ v441/n7096/full/441914a.html>

${ }^{14}$ Ibidem, s. 555.

${ }^{15}$ Ibidem.

${ }^{16}$ D. Butler: Open-access journal hits rocky times. „Nature” 2006 vol. 441 [online]. [dostęp: 16.07.2010]. Dostępny w World Wide Web: <http://www.nature.com/nature/journal/ v441/n7096/full/441914a.html>.

17 Ibidem. 
Obecnie sytuacja PLoS uległa polepszeniu. Częściowo korzysta wciąż z różnego typu grantów, dotacji i darowizn, jednak według raportu na rok 2009 organizacja zakłada, że w 2009 r. jej przychody pokryją ok. 85\% wydatków, natomiast w 2010 r. uzyska już pełną niezależność finansowa ${ }^{18}$. Chociaż PLoS jest organizacją non profit, jej działalność można określić jako model hybrydowy, w pewnych aspektach bowiem działa ona jako typowe przedsiębiorstwo rynkowe ${ }^{19}$. OA stał się jednym z modeli biznesowych, odkąd komercyjne wydawnictwa dostrzegły korzyści finansowe w jego publikowaniu. Wystarczy spojrzeć na przejęcie przez Springer Verlag wydawnictwa BioMed Central w 2008 roku $^{20}$.

Wyjście PLoS z kryzysu, odbyło się jednak poprzez podniesienie kosztów obciążających autorów. Tak, jak się spodziewano, w ciągu ostatnich kilku lat opłaty ponoszone przez autorów chcacych publikować na łamach czasopism PLoS wzrosły prawie dwukrotnie. Według aktualnego cennika dostępnego na stronie PLoS artykuły w tytułach wydawanych przez wydawnictwo wynosza: 2250 dolarów w przypadku „PLoS Computational Biology”, „PLoS Genetics”, „PLoS Pathogens” i „PLoS Neglected Tropical Diseases”, 2900 w przypadku "PLoS Medicine” i „PLoS Biology”, jedynie publikowanie w interdyscyplinarnym czasopiśmie „PLoS ONE” kosztuje autora obecnie 1350 dolarów ${ }^{21}$. Na preferencyjne warunki finansowe (zniżka 10\%) mogą liczyć autorzy, których instytucje legitymują się członkowstwem w PLoS. Wydawnictwo uruchomiło również specjalny program pomocowy dla tych autorów, których nie stać na samodzielne pokrycie opłat, polegający na całkowitym lub częściowym umorzeniu należności22.

BioMed Central również pobiera opłaty autorskie za publikowanie na łamach większości swoich 206 czasopism. Wynoszą one od 760 dolarów w przypadku takich czasopism jak: „Journal of Cheminformatics” i „Chemistry Central Journal” do 2440 dolarów w przypadku "Genome Medicine" czy „Genome Biology”. Tytuły: „Sports Medicine, Arthroscopy, Rehabilitation, Therapy \& Technology”, "Scandinavian Journal of Trauma, Resuscitation and Emergency Medicine", "Journal of the International AIDS Society”, „Journal of Orthopaedic Surgery and Research", „Journal of Biomedical Science”, "Italian Journal of Pediatrics”, „Chiropractic \& Osteopathy” i „Chinese Medicine” są całkowicie zwolnione z oplat autorskich, natomiast nowy tytuł "Journal of Systems Chemistry" jest objęty promocyjnym okresem zwolnienia ${ }^{23}$.

Coraz więcej komercyjnych wydawców sięga po model Open Access również dlatego, że jest to dobra forma promocji. Niektórzy wydawcy udostępniają tytuły w całkowicie otwartym dostępie lub zapewniają dostęp do artykułów po upływie określonego okresu karencji. Takie tytuły finansowane są przez ich

${ }^{18}$ PLoS Progress Report June 2009. [online]. [dostęp: 10.08.2010]. Dostępny w World Wide Web: <http://www.plos.org/downloads/progress_report.pdf>.

${ }^{19}$ Ibidem.

${ }^{20}$ Ibidem.

${ }^{21}$ Publication Fees for PLoS Journals. [online]. [dostęp: 15.08.2010]. Dostępny w World Wide Web: <http://www.plos.org/journals/pubfees.php>.

${ }^{22}$ Ibidem.

23 Frequently asked questions about BioMed Central's article-processing charges. [online]. [dostęp: 17.07.2010]. Dostępny w World Wide Web: <http://www.biomedcentral.com/ info/about/apcfaq>. 
komercyjne wersje lub przeznacza się na nie środki z wpływów pochodzących $z$ innych czasopism danego wydawcy, udostępnianych komercyjnie. Istnieje również model hybrydowy, w przypadku którego część artykułów w obrębie jednego tytułu czasopisma może być udostępniona w wolnym dostępie, natomiast dostęp do pozostałych jest odpłatny. W przypadku niektórych tego typu czasopism, gdzie zwykle stosowany jest model polegający na subskrypcji, autor, po dokonaniu opłaty, może „uwolnić" swój artykuł, tak aby był on dostępny dla wszystkich w wolnym dostępie. Pierwszym czasopismem, które zastosowało model hybrydowy był „Florida Journal of Entomology”. Obecnie praktycznie każde wydawnictwo naukowe daje autorom możliwość publikowania w tym modelu, np. Cambridge University Press: „Cambridge Open Option”, Elsevier: „Sponsored Article”, Nature Publishing Group („British Journal of Cancer”): „BJC OPEN, („British Journal of Pharmacology”): „BJP Open”, Oxford University Press: „Oxford Open”, Royal Society (UK): „EXiS Open Choice”, Springer: „Open Choice”.

Różnica pomiędzy OA a hybrydowym OA polega również na tym, że w modelu hybrydowym publikacja często opatrzona jest pewnymi restrykcjami dotyczącymi redystrybucji lub wykorzystania ${ }^{24}$.

Poniższa tabela przedstawia wysokość pobieranych przez wydawnictwa opłat autorskich:

\begin{tabular}{|c|c|c|}
\hline \multicolumn{3}{|c|}{ WYDAWCY OPEN ACCESS } \\
\hline Nazwa wydawcy & Wysokość opłaty autorskiej & Przykladowe tytuly \\
\hline BioMed Central & $\begin{array}{l}625-2365 \text { \$, średnio } 1535 \$ \\
\text { (15\% na podstawie czlonkostwa } \\
\text { UCB membership) }\end{array}$ & $\begin{array}{l}\text { BMC Evolutionary Biology, BMC } \\
\text { Informatics, Genome Biology, } \\
\text { Nutrition Journal }\end{array}$ \\
\hline Co-Action Publishing & $\begin{array}{l}\text { od } 65 € \text { za stronę do } 712 € \text { za } \\
\text { artykuł }\end{array}$ & $\begin{array}{l}\text { Food and Nutrition Research, Ethics } \\
\text { and Global Politics }\end{array}$ \\
\hline Hindawi Publishing & $600 \$-1500 \$$ & $\begin{array}{l}\text { International J. of Plant Genomics, } \\
\mathrm{J} \text {. of Applied Mathematics, } \\
\mathrm{J} \text {. of Nanomaterials, Modelling and } \\
\text { Simulation in Engineering }\end{array}$ \\
\hline Oxford University Press & $\begin{array}{l}1800 \text { \$ (jeśli mamy drukowana } \\
\text { subskrypcję) (2250 \$ od } \\
12.01 .09)\end{array}$ & Pełna oferta czasopism OA \\
\hline PhysMath Central & $\begin{array}{l}1515 \text { \$ (15\% zniżki na podstawie } \\
\text { członkostwa UCB membership) }\end{array}$ & PMC Physics A, PMC Physics B \\
\hline Public Library of Science (PLoS) & $\begin{array}{l}1350 \text { \$-2800 \$ (10\% zniżki na } \\
\text { podstawie UC membership) }\end{array}$ & $\begin{array}{l}\text { PLoS Biology, PLoS Computational } \\
\text { Biology, PLoS Medicine, PLoS One }\end{array}$ \\
\hline \multicolumn{3}{|c|}{ WYDAWCY HYBRYDOWEGO MODELU OA } \\
\hline $\begin{array}{c}\text { Nazwa wydawcy (nazwa } \\
\text { programu OA) }\end{array}$ & Wysokość opłaty autorskiej & Tytuły czasopism \\
\hline $\begin{array}{l}\text { American Chemical Society } \\
\text { (ACS Author Choice) }\end{array}$ & $1500 \$-3000 \$$ & $\begin{array}{l}\text { ACS Chemical Biology, Analytical } \\
\text { Chemistry, J. of the American } \\
\text { Chemical Society, J. of Organic } \\
\text { Chemistry }\end{array}$ \\
\hline
\end{tabular}

${ }^{24}$ Selective list of Open Access and Paid Access Fees. [online]. [dostęp: 15.08.2010]. Dostępny w World Wide Web: <http://www.lib.berkeley.edu/scholarlycommunication/oa_fees.html>. 


\begin{tabular}{|c|c|c|}
\hline $\begin{array}{l}\text { American Institute of Physics } \\
\text { (AIP) } \\
\text { (Author Select) }\end{array}$ & $1500 \$-1800 \$, 2500 \$$ & $\begin{array}{l}\text { Applied Physics Letters, Chaos, } \\
\text { J. of Mathematical Physics, } \\
\text { J. of Rheology }\end{array}$ \\
\hline $\begin{array}{l}\text { American Physical Society (APS) } \\
\text { (Free to Read) }\end{array}$ & $975 \$, 1300 \$$ & $\begin{array}{l}\text { Physical Review A-E, Physical } \\
\text { Review Letters, Reviews of Modern } \\
\text { Physics }\end{array}$ \\
\hline $\begin{array}{l}\text { Blackwell Publishing } \\
\text { (Online Open) }\end{array}$ & $2600 \$$ & $\begin{array}{l}\text { International Review of Finance, } \\
\text { International Statistical Review, } \\
\text { Renaissance Studies, J. of Applied } \\
\text { Crystallography }\end{array}$ \\
\hline $\begin{array}{l}\text { Cambridge Journals } \\
\text { (Cambridge Open Option) }\end{array}$ & $1700 \$$ & $\begin{array}{l}\text { American Political Science Review, } \\
\text { Geological Magazine, J. of Social } \\
\text { Policy, Systematics and Biodiversity }\end{array}$ \\
\hline $\begin{array}{l}\text { Cold Spring Harbor Laboratory } \\
\text { Press } \\
\text { (Open Access Option) }\end{array}$ & $2000 \$$ & tylko Genome Research \\
\hline $\begin{array}{l}\text { Elsevier } \\
\text { (Sponsored Articles dostępny dla } \\
\text { ok. } 40 \text { z } 1800 \text { tytulów) }\end{array}$ & $3000 \$$ & $\begin{array}{l}\text { Discrete Applied Mathematics, } \\
\text { J. of Molecular Biology, Physics } \\
\text { Letters B, Vision Research }\end{array}$ \\
\hline $\begin{array}{l}\text { National Academy of Sciences } \\
\text { (Open Access Option) }\end{array}$ & $\begin{array}{l}950 \text { \$ (w ramach UCB } \\
\text { membership) }\end{array}$ & $\begin{array}{l}\text { Proceedings of the National } \\
\text { Academy of Sciences (PNAS) }\end{array}$ \\
\hline $\begin{array}{l}\text { Oxford Journals } \\
\text { (Oxford Open - optional open } \\
\text { access model) }\end{array}$ & $1500 \$$ & $\begin{array}{l}\text { Biostatistics, Health Policy and } \\
\text { Planning, J. of Design History, } \\
\text { Quarterly J. of Mathematics }\end{array}$ \\
\hline $\begin{array}{l}\text { Royal Society of Chemistry } \\
\text { (RSC) } \\
\text { (RSC Open Science) }\end{array}$ & $\begin{array}{l}1800 \$-4500 \$(15 \% \text { zniżki } \\
\text { w przypadku subskrypcji) }\end{array}$ & $\begin{array}{l}\text { Chemical Biology, Geochemical } \\
\text { Transactions, Methods in Organic } \\
\text { Synthesis }\end{array}$ \\
\hline $\begin{array}{l}\text { Springer } \\
\text { (Open Choice) }\end{array}$ & $2000 € / 3000 \$$ & $\begin{array}{l}\text { Acoustical Physics, Computational } \\
\text { Economics, Current Psychology, } \\
\text { J. of Religion and Health }\end{array}$ \\
\hline $\begin{array}{l}\text { Taylor and Francis } \\
\text { (iOpenAccess) }\end{array}$ & $3100 \$$ & $\begin{array}{l}\text { Annals of Human Biology, Food } \\
\text { Biotechnology, International } \\
\text { J. of Computer Mathematics, } \\
\text { Philosophical Psychology }\end{array}$ \\
\hline $\begin{array}{l}\text { Wiley InterScience } \\
\text { (Funded Access for biomedical } \\
\text { titles) }\end{array}$ & $3000 \$$ & $\begin{array}{l}\text { J. of Basic Microbiology, Proteomics, } \\
\text { Statistics in Medicine }\end{array}$ \\
\hline $\begin{array}{l}\text { World Scientific } \\
\text { (WorldSciNet OPEN ACCESS) }\end{array}$ & $2500 \$$ & $\begin{array}{l}\text { International J. of Mathematics, } \\
\text { Modern Physics Letters B }\end{array}$ \\
\hline
\end{tabular}

Obok wydawnictw, które pobierają opłaty od autorów nadsyłających teksty, są również takie, które opłat nie pobierają. W zasadzie ponad dwie trzecie czasopism z listy Directory of Open Access Journals (DOAJ) i ponad 80\% czasopism OA wydawanych przez towarzystwa naukowe nie pobiera opłat od autorów ${ }^{25}$. Czasopisma te utrzymywane są z dotacji rządowych, grantów lub z pieniędzy towarzystw naukowych i instytucji, pod których szyldem funkcjonują. Wiele instytucji i organizacji finansujących badania naukowe, zwłaszcza tych,

${ }^{25}$ B. Hooker: If it won't sink in, maybe we can pound it in ... [online]. [dostęp: 19.07.2010]. Dostępny w World Wide Web: <http://www.sennoma.net/main/archives/2007/12/if_it_wont_ sink_in_maybe_we_ca.php>. 
które dysponują środkami publicznymi, nakłada na grantobiorców obowiązek publikowania wyników badań w czasopiśmie lub repozytorium OA. Niektóre czasopisma i repozytoria powstaja właśnie w celu publikowania wyników badań przez grantobiorców konkretnej organizacji.

Po przeanalizowaniu różnych przypadków nasuwa się stwierdzenie, że najlepszym rozwiązaniem byłoby finansowanie OA za pomoca modelu mieszanego. Częściami składowymi opłat ponoszonych przez autorów powinny być fundusze pochodzące $z$ macierzystych placówek i instytucji, z organizacji finansujacych badania naukowe oraz funduszy rzadowych. Fora do publikowania wyników badań naukowych powinny również tworzyć instytuty naukowe oraz wyższe uczelnie, tworząc repozytoria, elektroniczne archiwa publikacji oraz recenzowane czasopisma naukowe, za publikowanie w których ani autor, ani jednostka, z której się wywodzi, nie musiałaby ponosić opłat.

Wielu zwolenników Open Access, podkreśla, że podobnie jak w przypadku badań nad AIDS czy innymi chorobami ponad kwestie finansowe powinien być ważniejszy interes i dobro ludzkości. Tym bardziej w przypadku, kiedy badania te prowadzone są za pieniądze publiczne. W modelu OA chodzi bowiem zasadniczo o to, aby podatnik finansujący badania naukowe nie musiał płacić za dostęp do ich wyników. W większości wypadków komercyjne wydawnictwa utworzyły na tej podstawie nowy, zyskowny model biznesowy, w którym opłaty z czytelnika zostały przeniesione na autora.

\section{Summary}

Funding Open Access is an extremely important question, however hardly mentioned in Polish literature. The Open Access model, assumed to assure free access to resources, generates system, organizational, and administrative costs, which we shall be aware of. The author discusses current methods of Open Access publications' funding, like: author, institutional, double, shared, and hybrid models, as well as governmental funding, grants, and payable membership in an OA publishing house. Particular attention is put on an author model of financing OA publications, assuming that costs of publishing texts are paid by their authors. The levels of authorship fees in most of commercial OA and hybrid journals' publishers are described. 